Brit. J. vener. Dis. (1963), 39, 164.

\title{
AMPICILLIN ("PENBRITIN") IN THE TREATMENT OF GONORRHOEA*
}

\author{
BY
}

R. R. WILLCOX

St. Mary's Hospital, London, W.2

Oral antibiotic therapy for the treatment of gonorrhoea, while offering some advantages in lightening the load of both clinic and physician, has not so far had the approval of most venereologists. Patients have varying powers of absorption of drugs taken orally, may not take them at the times requested or in the amounts prescribed, and may hold untaken doses in reserve for self-medication for similar conditions at a later date-with all its potential dangers, from concealing a syphilitic infection to fostering a "black market".

Most of these difficulties can be overcome if good therapeutic results can be achieved by giving a single oral dose under supervision in the clinic-or at the most two doses a few hours apart. This paper concerns one of the newer penicillins-ampicillin ("Penbritin")-used in this way. This substance, $\alpha$-aminobenzylpenicillin, is a semi-synthetic penicillin derived from the penicillin nucleus 6-aminopenicillanic acid which was isolated in 1957. It is effective against a wide range of Gram-positive and Gram-negative organisms and is produced in dual black/red capsules each of $250 \mathrm{mg}$.

Ampicillin was tested against the gonococcus in vitro by Ödegaard (1962) and, although it had a somewhat weaker effect on most gonococcal strains than benzyl penicillin $G$, it had a better effect on the least sensitive strains and was superior to the other orally-administered penicillins, phenethicillin and phenoxymethyl penicillin.

\section{Case Material}

200 male patients with uncomplicated acute gonorrhoea have been treated with ampicillin: 150 received single doses of 0.5-1 g. and fifty received an initial dose of $1 \mathrm{~g}$. followed 5 to 6 hours later by a further dose of $1 \mathrm{~g}$.

\footnotetext{
- Received for publication July 4, 1963.
}

95 of these patients were Negroes (86 from the West Indies, seven from West Africa, one from East Africa, and one from South Africa), 64 were from the United Kingdom, twelve from Eire, four from South Italy, four from Pakistan, three from Poland, two from Egypt, two from Malta, and one each from Australia, Austria, Canada, Ceylon, Cyprus, India, Lebanon, Mauritius, Singapore, South Africa, Spain, Switzerland, Turkey, and the U.S.A. The average age was $27 \cdot 8$ years (range 16 to 56). 24 were married and 166 were single.

79 patients had had no previous venereal incident. The remainder had had 340 previous incidents, including 264 attacks of gonorrhoea, 54 of non-gonococcal urethritis, eight of syphilis, three of genital sore, two of scabies, one of epididymitis, one of condylomata acuminata, one of herpes genitalis, and six of anxiety concerning venereal disease. 247 of the 340 previous incidents had been experienced by the 95 Negroes who thus averaged 2.6 previous attacks each compared with 0.9 previous attacks each for those of other races. Six West Indian patients had had from 11 to 22 previous attacks of gonorrhoea each.

The discharge had been present before treatment for 1 to 3 days in 141 cases, for 4 to 7 days in 49 , for 8 to 14 days in nine, and for longer than this time in one; 162 patients complained of some dysuria. The disease was stated to have been caught from a stranger in 107 instances, from a friend in 74, from another man in eight, and from the wife in six; in five cases the source was unknown.

The apparent incubation period was 1 to 3 days in eighty cases, 4 to 7 in 65,8 to 14 in 26,15 to 21 in 6,22 to 28 in four, and one month in six; in thirteen cases it was not known.

The routine Wassermann and VDRL (or Kahn) reactions were both negative in 180 cases, the Wassermann was negative and the other test positive in thirteen cases, and both were positive in seven cases. All but one of the sera positive to both tests and all but two positive to one test were from Negro patients, so that this positivity was probably due to past yaws in some instances. The gonococcal complement-fixation test was negative in 34 of 37 sera tested. 


\section{Case Management}

In all cases the gonococcus was found in Gramstained urethral smears before treatment when routine serum tests for syphilis were also made. The single doses of ampicillin were administered under supervision in the clinic, or the first dose was given in the clinic and the patient was given a further dose to take after 5 to 6 hours. An injection of $1 \mathrm{ml}$. distilled water was also administered intramuscularly.

Fifty patients received a single, oral dose of $0.5 \mathrm{~g}$. (two capsules), fifty had a single dose of $0.75 \mathrm{~g}$. (three capsules), fifty had a single dose of $1 \mathrm{~g}$. (four capsules), and the other fffty received two doses each of $1 \mathrm{~g}$. (total $2 \mathrm{~g}$.) at an interval of 5 to 6 hours.

After treatment it was planned to see the patients again after 2 to 3 days and after 7 to 14 days (with an examination of the prostatic secretion), again at 28 days, and subsequently-for those who could be persuaded to attend-at 56 days with final serum tests for syphilis at 90 days. At each visit the urethra was examined for signs of urethral discharge (a smear being taken if present) and the urine for haze and threads.

\section{Follow-up and Results}

The follow-up and results are shown in Table I. Not all patients attended when requested, but sufficient time has elapsed for all patients to have attended for at least 2 months from treatment. One non-Negro patient, unable to take oral medication, vomited his tablets at once and has been excluded from the study.

\section{TABLE I}

FOLLOW-UP AND RESULTS OBTAINED WITH 0 5-2g.
AMPICILLIN

\begin{tabular}{|c|c|c|c|c|c|}
\hline \multirow[b]{2}{*}{$\begin{array}{c}\text { Follow- } \\
\text { up }\end{array}$} & \multirow[b]{2}{*}{$\begin{array}{l}\text { No. } \\
\text { Followed }\end{array}$} & \multicolumn{4}{|c|}{ Results } \\
\hline & & $\begin{array}{l}\text { Satis- } \\
\text { factory }\end{array}$ & $\begin{array}{c}\text { Non- } \\
\text { Gonococcal } \\
\text { Urethritis }\end{array}$ & $\begin{array}{c}\mathrm{Re}- \\
\text { infection }\end{array}$ & Failure \\
\hline $\begin{array}{c}0 \\
1-7 \text { days } \\
8-14 \text { days } \\
15-21 \text { days } \\
22-28 \text { days } \\
1-2 \text { mths } \\
2-3 \text { mths } \\
\text { Over } \\
3 \text { mths }\end{array}$ & $\begin{array}{r}199 \\
175 \\
94 \\
59 \\
47 \\
34 \\
15 \\
9\end{array}$ & $\begin{array}{r}\overline{62} \\
16 \\
7 \\
5 \\
13 \\
3 \\
1\end{array}$ & $\begin{array}{c}\overline{5} \\
12 \\
2 \\
1^{*} \\
3 \\
1 \\
1\end{array}$ & $\begin{array}{c}- \\
3 \\
1 \\
3 \\
3 \\
2 \\
7 \dagger\end{array}$ & $\begin{array}{r}\overline{14} \\
4 \\
2 \\
4 \\
= \\
=\end{array}$ \\
\hline Total & 175 & 107 & 25 & 19 & $\begin{array}{c}24 \\
(13.7 \%)\end{array}$ \\
\hline
\end{tabular}

* Pus in prostatic secretion only.

$\dagger$ One of which was a rectal infection.

Thus, of 175 patients followed, the condition was found to be satisfactory in 107 at the last visit; 25 were subsequently re-treated for non-gonococcal infection and nineteen for apparent re-infection and there were 24 apparent failures (13.7 per cent. of those followed).

There are no satisfactory criteria to distinguish relapse from re-infection apart from a history of further sexual exposure. Indeed, in many cases of apparent failure, further intensive questioning may induce the patient to admit to having taken further risks. However, it is noted that eighteen of the 24 suspected relapses were reported within 2 weeks of treatment while sixteen of the nineteen suspected re-infections occurred after this interval.

Side-Effects.-Apart from the patient referred to above who immediately vomited the capsules, one patient had diarrhoea with about three stools daily for 3 days, one stated that his furred tongue of 2-years' duration was worse after taking the drug, and one with a history of asthma developed a slight urticaria within 2 days which was well controlled by an antihistamine drug.

Results in White and Negro patients.-There was nothing to suggest that the failure rates were higher in Negro patients than in those of other groups (Table II).

TABLE II

RESULTS IN WHITE AND NEGRO PATIENTS

\begin{tabular}{|c|c|c|c|c|c|c|}
\hline \multirow[b]{2}{*}{ Race } & \multirow{2}{*}{$\begin{array}{c}\text { No. } \\
\text { Treated }\end{array}$} & \multicolumn{5}{|c|}{ Results } \\
\hline & & $\begin{array}{l}\text { No. } \\
\text { Fol- } \\
\text { lowed }\end{array}$ & $\begin{array}{l}\text { Non- } \\
\text { gonococcal } \\
\text { Urethritis }\end{array}$ & $\begin{array}{c}\text { Re-in- } \\
\text { infec- } \\
\text { tion }\end{array}$ & Failure & $\begin{array}{l}\text { Per cent. } \\
\text { Failure of } \\
\text { Those } \\
\text { Followed }\end{array}$ \\
\hline $\begin{array}{l}\text { Negroes } \\
\text { Others }\end{array}$ & $\begin{array}{r}95 \\
104\end{array}$ & $\begin{array}{l}85 \\
90\end{array}$ & $\begin{array}{r}19 \\
6\end{array}$ & $\begin{array}{r}9 \\
10\end{array}$ & $\begin{array}{l}10 \\
14\end{array}$ & $\begin{array}{l}11 \cdot 8 \\
15 \cdot 6\end{array}$ \\
\hline Total & 199 & 175 & 25 & 19 & 24 & $13 \cdot 7$ \\
\hline
\end{tabular}

Results of Four Schedules Compared.-The results obtained with the four schedules of treatment are compared in Table III. There is no clear superiority for any schedule; indeed, single doses of $0.5 \mathrm{~g}$. were apparently as successful as the higher dosages of $0 \cdot 75,1$, and $2 \mathrm{~g}$.

TABLE III

RESULTS OF FOUR SCHEDULES COMPARED

\begin{tabular}{|c|c|c|c|c|c|c|c|}
\hline \multirow[b]{2}{*}{$\begin{array}{c}\text { Dosage } \\
(\mathrm{g} .)\end{array}$} & \multirow{2}{*}{$\begin{array}{c}\text { No. } \\
\text { of } \\
\text { Doses }\end{array}$} & \multirow{2}{*}{$\begin{array}{c}\text { No. } \\
\text { Trea- } \\
\text { ted }\end{array}$} & \multirow{2}{*}{$\begin{array}{c}\text { No. } \\
\text { Fol- } \\
\text { lowed }\end{array}$} & \multicolumn{4}{|c|}{ Results } \\
\hline & & & & $\begin{array}{c}\text { Non- } \\
\text { gono- } \\
\text { coccal } \\
\text { Urethritis }\end{array}$ & $\begin{array}{c}\text { Re- } \\
\text { infec- } \\
\text { tion }\end{array}$ & $\begin{array}{c}\text { Fail- } \\
\text { ure }\end{array}$ & $\begin{array}{l}\text { Per cent. } \\
\text { Failure of } \\
\text { Those } \\
\text { Followed }\end{array}$ \\
\hline $\begin{array}{l}0.5 \mathrm{~g} . \\
1.75 \mathrm{~g} . \\
1 \mathrm{~g} . \\
2 \mathrm{~g} .\end{array}$ & $\begin{array}{l}1 \\
1 \\
1 \\
2\end{array}$ & $\begin{array}{l}49 \\
50 \\
50 \\
50\end{array}$ & $\begin{array}{l}42 \\
44 \\
46 \\
43\end{array}$ & $\begin{array}{l}6 \\
6 \\
7 \\
6\end{array}$ & $\begin{array}{l}6 \\
5 \\
4 \\
4\end{array}$ & $\begin{array}{l}5 \\
7 \\
7 \\
5\end{array}$ & $\begin{array}{l}11 \cdot 9 \\
15 \cdot 9 \\
15 \cdot 2 \\
11 \cdot 6\end{array}$ \\
\hline Total & - & 199 & 175 & 25 & 19 & 24 & $13 \cdot 7$ \\
\hline
\end{tabular}


Comparison with Results from Penicillin by Injection.-The results obtained with ampicillin proved comparable to those obtained with single injections of 1.2 mega units aqueous procaine penicillin given under similar conditions during the same time (Table IV).

TABLE IV

RESULTS OBTAINED WITH $1 \cdot 2$ MEGA UNITS AQUEOUS PROCAINE PENICILIIN

\begin{tabular}{|c|c|c|c|c|c|}
\hline \multirow{2}{*}{$\begin{array}{l}\text { Follow- } \\
\text { up }\end{array}$} & \multirow{2}{*}{$\begin{array}{c}\text { No. } \\
\text { Followed }\end{array}$} & \multicolumn{4}{|c|}{ Results } \\
\hline & & $\begin{array}{l}\text { Satis- } \\
\text { factory }\end{array}$ & $\begin{array}{c}\text { Non- } \\
\text { gonococcal } \\
\text { Infection }\end{array}$ & $\underset{\text { infection }}{\mathrm{Re}-}$ & Failure \\
\hline $\begin{array}{c}0 \\
\text { 1-3 days } \\
4-7 \text { days } \\
8-14 \text { days } \\
15-21 \text { days } \\
22-28 \text { days } \\
1-2 \text { mths } \\
\text { 2-3 mths } \\
\text { More than } \\
3 \text { mths }\end{array}$ & $\begin{array}{r}279 \\
207 \\
170 \\
120 \\
51 \\
57 \\
49 \\
21 \\
10\end{array}$ & $\begin{array}{r}31 \\
34 \\
24 \\
13 \\
5 \\
13 \\
2 \\
1\end{array}$ & $\begin{array}{l}-2 \\
8 \\
5 \\
3 \\
2 \\
4 \\
4 \\
2\end{array}$ & $\begin{array}{l}- \\
1 \\
4 \\
5 \\
9 \\
5 \\
7\end{array}$ & $\begin{array}{l}-4 \\
7 \\
6 \\
3 \\
1 \\
2 \\
-\end{array}$ \\
\hline Total & 207 & 123 & 30 & 31 & $\begin{array}{l}23(11 \cdot 1 \\
\text { per cent.) }\end{array}$ \\
\hline
\end{tabular}

Of 279 patients treated with a single injection of procaine penicillin, 207 were followed and there were $23(11 \cdot 1$ per cent.) failures during 3 posttreatment months.

Comparison of Ampicillin with Other Drugs given in Single Doses. - Table V compares the results obtained with a single oral dose of ampicillin with those personally obtained with a single dose of other antibiotic preparations.

TABLE V

COMPARISON OF AMPICILLIN WITH OTHER ANTIBIOTIC PREPARATIONS GIVEN IN SINGLE ORAL DOSES

\begin{tabular}{|c|c|c|c|c|c|}
\hline Drug & \begin{tabular}{|} 
Single \\
Dose (g.)
\end{tabular} & $\begin{array}{l}\text { No. } \\
\text { Treated }\end{array}$ & $\begin{array}{l}\text { No. } \\
\text { Followed }\end{array}$ & $\begin{array}{l}\text { No. of } \\
\text { Failures }\end{array}$ & $\begin{array}{l}\text { Per cent. } \\
\text { Failures }\end{array}$ \\
\hline Ampicillin & $\begin{array}{l}0.5 \\
0.75-1\end{array}$ & $\begin{array}{r}49 \\
100\end{array}$ & $\begin{array}{l}42 \\
90\end{array}$ & $\begin{array}{r}5 \\
14\end{array}$ & $\begin{array}{l}11.9 \\
15.6\end{array}$ \\
\hline Phenethicillin ${ }^{1}$ & 1 & 25 & 22 & 6 & $27 \cdot 3$ \\
\hline $\begin{array}{l}\text { Phenoxy- } \\
\text { methyl }(V)^{2}\end{array}$ & $\begin{array}{l}1 \cdot 25 \\
1 \cdot 875\end{array}$ & $\begin{array}{l}21 \\
22\end{array}$ & $\begin{array}{l}20 \\
17\end{array}$ & $\begin{array}{l}4 \\
1\end{array}$ & $\begin{array}{r}20 \cdot 0 \\
5 \cdot 9\end{array}$ \\
\hline $\begin{array}{c}\text { Benzathine } \\
\text { Penicillin's }^{3}\end{array}$ & $\begin{array}{c}4 \cdot 8 \text { mega } \\
\text { units }\end{array}$ & 45 & 43 & 16 & $37 \cdot 2$ \\
\hline $\begin{array}{c}\text { Oxytetra- } \\
\text { cycline }\end{array}$ & 2 & 37 & 29 & 5 & $17 \cdot 2$ \\
\hline
\end{tabular}

${ }^{1}$ Willcox (1962). ${ }^{2}$ Willcox (1958). ${ }^{3}$ Willcox (1954).

Better results were obtained with $0.5 \mathrm{~g}$. ampicillin than with four times the dosage of oxytetracycline, and these results were substantially better than those obtained with double the dose of phenethicillin or of phenoxymethyl penicillin. Benzathine penicillin proved entirely unsatisfactory.

\section{Summary}

(1) 200 male patients with uncomplicated acute gonorrhoea were treated with a single oral dose of $0 \cdot 5,0 \cdot 75$, or $1 \mathrm{~g}$. ampicillin, or with two doses each of $1 \mathrm{~g}$. taken 5 to 6 hours apart.

(2) No serious side-effects were noted. Of 175 patients followed, the condition at the last visit was satisfactory in $107 ; 25$ were subsequently treated for a non-gonococcal infection, nineteen for a re-infection with gonorrhoea, and 24 (13.7 per cent. of those followed) were regarded as failures.

(3) There was no evidence of a higher failure rate in Negroes than in those of other races.

(4) A comparison of the four schedules indicated no real advantage in increasing the dose of ampicillin above a single dose of $0.5 \mathrm{~g}$., with which a failure rate of 11.9 per cent. was obtained in those followed.

(5) The results obtained with ampicillin proved comparable to those achieved with single injections of aqueous procaine penicillin under similar conditions during the same period. Dose for dose the results with ampicillin proved superior to those obtained with phenethicillin and with larger doses of phenoxymethyl penicillin.

(6) Ampicillin represents a useful addition to the therapy of gonorrhoea.

Grateful acknowledgements are expressed to Beecham Research Laboratories of Brentford, Middlesex, England, for kindly providing the "Penbritin" used in this study.

\section{REFERENCES}

Odegaard, K. (1962). Brit. med.J., $1,645$.

Willcox, R. R. (1953). Med. Press, 229, 535. - (1954). Amer J. Syph., 38, 469. (1958). Brit. J. vener. Dis., 34, 118. (1962). Ibid., 38, 57.

La blennorragie traitée par l'ampicilline (Penbritin)

\section{RÉSUMÉ}

(1) On donna une seule dose de $0,5,0,15$ ou 1 g., ou deux doses de $1 \mathrm{~g}$. d'ampicilline à 200 hommes atteints de blennorragie simple.

(2) On ne vit aucune réaction toxique. Sur 175 malades suivis, 107 furent guéris, 25 eurent besoin de traite- 
ment pour infection non-gonococcique, 19 furent atteints de nouveau, et il y eut 24 rechutes $(13,7 \%$ des sujets suivis).

(3) Les rechutes ne furent pas plus nombreuses parmi les nègres.

(4) Il ne sembla pas nécessaire de donner plus d'une seule dose de $0,5 \mathrm{~g}$. d'ampicilline, traitement avec lequel il y eut $11,9 \%$ de rechutes.
(5) Les résultats obtenus avec l'ampicilline furent aussi bons que ceux que donne généralement une seule injection de pénicilline procaine aqueuse dans des circonstances semblables pendant le même temps. L'ampicilline se montra supérieure aux mêmes doses de phénéthicilline et à des doses plus fortes de phénoxyméthyle pénicilline.

(6) L'ampicilline représente une addition utile à la thérapeutique de la gonorrhée. 